\title{
INVESTIGATION OF BLOCK TO GONADOTROPHIN RELEASE IN MATURE FEMALE RATS
}

\author{
J. P. BENNETT,* D. K. VALLANCE AND B. H. VICKERY \\ The Biological Research Department, B.D.H. (Research) Limited, \\ Godalming, Surrey
}

(Received 3rd February 1967)

\begin{abstract}
Summary. The block to gonadotrophin release in mature female rats caused by an oestrogen, a progestin and an androgen has been investigated by replacement with pregnant mare serum gonadotrophin (PMSG) and human chorionic gonadotrophin (HCG). Inhibition of ovulation produced by the progestin could be reversed by HGG alone but the effects upon ovulation of oestrogen and androgen were not reversed unless both PMSG and HCG were supplied. The relevance of the results to previous work in the rat and other species is discussed.
\end{abstract}

\section{INTRODUCTION}

Previous workers have attempted to ascertain the mechanism of the inhibition of ovulation produced by gonadal steroids in the female rat (Greep \& Jones, 1950; Van Rees, 1961, among others). The reports in the literature, however,

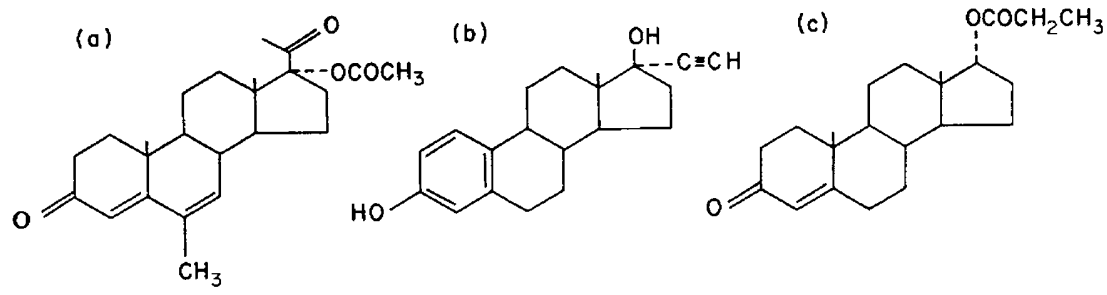

Text-Fig. 1. Structural formulae of (a) megestrol acetate, (b) ethinyl oestradiol, and (c) testosterone propionate.

conflict as to whether the action of follicle stimulating hormone (FSH) or of luteinizing hormone $(\mathbf{L H})$ is primarily involved.

Makepeace, Weinstein \& Friedman (1937) have shown that inhibition of ovulation in the rabbit by doses of progestin may be reversed with exogenous LH, suggesting that the progestin inhibits the release or production of $\mathbf{L H}$ at either pituitary or hypothalamic levels. A similar approach has now been used in the rat in the hope that further information on the mechanism of inhibition of ovulation by a progestin (megestrol acetate), an oestrogen (ethinyl oestradiol) and an androgen (testosterone propionate) might result (Text-fig. 1).

\footnotetext{
* Present address: Institute of Hormone Biology, Syntex, Stanford Industrial Park, Palo Alto, California.
} 


\section{MATERIALS AND METHODS}

Virgin, specific pathogen-free, albino rats (200 to $250 \mathrm{~g}$ ), obtained from our own colony, were given aureomycin $(50 \mathrm{mg} / \mathrm{l})$ in the drinking water as a prophylactic for 1 week before, and for the duration of, the experiment (Bennett, Vallance \& Vickery, 1967).

Each steroid under examination was administered daily to groups of 5 to 10 animals for 14 days. Megestrol acetate and ethinyl oestradiol were given orally as suspensions in an aqueous medium composed of $1.2 \% \mathrm{w} / \mathrm{v}$ carboxy methyl cellulose, $1.5 \% \mathrm{w} / \mathrm{v}$ Tween 80 and distilled water to $100 \%$. The dose volumes were adjusted to $25 \mathrm{ml} / \mathrm{kg}$ body weight. Testosterone propionate was administered subcutaneously twice daily (09.00 hours and 16.30 hours) as a solution in a 1:4 mixture of ethyl oleate and arachis oil. The dose volume was adjusted to $2 \mathrm{ml} / \mathrm{kg}$ body weight. Each animal was also injected intraperitoneally with a $1 \%$ aqueous solution of Dianil blue $2 \mathrm{R}(3 \mathrm{ml} / \mathrm{rat})$ on Days 5 to 8 of treatment inclusive (Bennett et al., 1967) while pregnant mare serum gonadotrophin, PMSG ('Pabyrn', Paines \& Byrne) and/or HCG ('Pregnyl', Organon) were administered intraperitoneally on Days 9 and 11 of the experiment, respectively, to some of the steroid-treated groups. All animals were killed on Day 15 of the experiment and the ovaries inspected for the occurrence of ovulation indicated by the presence of colourless or pink corpora lutea on the otherwise dark blue ovaries.

\section{RESULTS}

It can be seen from Table 1 that complete inhibition of ovulation was obtained with megestrol acetate at a dose of $12 \mathrm{mg} / \mathrm{kg} /$ day and almost complete inhibition

\section{TABle 1}

EFFECT OF HCG ON OVULATION INHIBITION PRODUCED BY MEGESTROL ACETATE AND BY ETHINYL OESTRADIOL IN THE RAT

\begin{tabular}{c|c|c|c|c}
\hline Compound & $\begin{array}{c}\text { Dose } \\
(m g / \mathrm{kg} / \text { day })\end{array}$ & $\begin{array}{c}\text { HCG dose } \\
(\text { i.u. } / \text { rat })\end{array}$ & $\begin{array}{c}\text { \% rats } \\
\text { ovulating }\end{array}$ & $\begin{array}{c}\text { Mean no. } \\
\text { ovulations/ } \\
\text { rat ovulating }\end{array}$ \\
\hline Megestrol acetate & 12 & - & 0 & 0 \\
Megestrol acetate & 12 & 10 & 100 & $9 \cdot 0$ \\
Ethinyl oestradiol & 2 & - & 20 & $4 \cdot 0$ \\
Ethinyl oestradiol & 2 & 10 & 20 & $2 \cdot 5$ \\
\hline
\end{tabular}

* Ten rats were used/dose group.

of ovulation with ethinyl oestradiol at $2 \mathrm{mg} / \mathrm{kg} /$ day. When, however, HCG (10 i.u.) was administered to animals already receiving megestrol acetate, all the animals ovulated, the mean number of ovulations per rat being in agreement with figures obtained for spontaneous ovulation in our colony. The rats which received HCG as well as ethinyl oestradiol, however, showed no such return to normal. The number of animals ovulating was not increased and the mean number of ovulations per rat ovulating showed no significant difference from the mean number of ovulations resulting from dosing with ethinyl oestradiol alone. 
The results of a further examination of ethinyl oestradiol are shown in Table 2. In this experiment $2 \mathrm{mg} / \mathrm{kg} /$ day completely inhibited ovulation, and it is

TABLE 2

EFFECTS OF PMSG AND HGG ON OVULATION INHIBITION PRODUCED BY ETHINYL OESTRADIOL ( 2 MG/KG/DAY) IN THE RAT

\begin{tabular}{|c|c|c|c|c|}
\hline $\begin{array}{c}P M S G \text { dose } \\
(\text { i.u. } / \text { rat })\end{array}$ & $\begin{array}{c}\text { HCG dose } \\
(\text { i.u. } \text { rat })\end{array}$ & $\begin{array}{c}\text { No. of rats } \\
\text { group }\end{array}$ & $\begin{array}{c}\% \text { rats } \\
\text { ovulating }\end{array}$ & $\begin{array}{l}\text { Mean no. of } \\
\text { ovulationsl } \\
\text { rat ovulating }\end{array}$ \\
\hline $\begin{array}{r}- \\
2 \cdot 5 \\
5 \cdot 0 \\
10 \cdot 0 \\
20 \cdot 0 \\
40 \cdot 0 \\
2.5 \\
5 \cdot 0 \\
10 \cdot 0 \\
20 \cdot 0 \\
40 \cdot 0 \\
-\end{array}$ & $\begin{array}{c}- \\
- \\
- \\
- \\
- \\
- \\
10.0 \\
10.0 \\
10.0 \\
10.0 \\
10.0 \\
10.0\end{array}$ & $\begin{array}{r}14 \\
8 \\
8 \\
5 \\
9 \\
10 \\
9 \\
7 \\
9 \\
6 \\
8 \\
9\end{array}$ & $\begin{array}{r}0 \\
0 \\
0 \\
0 \\
0 \\
20 \\
90 \\
85 \\
90 \\
100 \\
100 \\
0\end{array}$ & $\begin{array}{c}0 \\
0 \\
0 \\
0 \\
0 \\
2 \cdot 5 \\
6 \cdot 7 \\
6 \cdot 8 \\
10.9 \\
26.5 \\
53 \cdot 5 \\
0\end{array}$ \\
\hline
\end{tabular}

evident that injections of both PMSG and HCG were necessary to overcome this inhibition. A dose of PMSG between 5 and 10 i.u. given in conjunction with 10 i.u. of HCG was required to produce normal ovulation. Doses of PMSG alone, up to 40 i.u., produced only a limited number of ovulations in a small proportion of the animals and no ovulations were seen after administration of HCG alone. High doses of PMSG in conjunction with HCG gave rise to superovulation.

Table 3 shows that both PMSG and HCG were necessary to reverse the inhibition of ovulation caused by testosterone propionate $(0.2 \mathrm{mg} / \mathrm{kg}$ twice daily).

TABLE 3

EFFECT OF ADMINISTRATION OF PMSG AND HCG ON THE INHIBITION OF OVULATION PRODUGED BY TESTOSTERONE PROPIONATE $(0 \cdot 2 \mathrm{MG} / \mathrm{KG}$ TWICE DAILY) IN THE RAT

\begin{tabular}{|c|c|c|c|c|}
\hline $\begin{array}{c}\text { PMSG dose } \\
\quad \text { (i.u./rat })\end{array}$ & $\begin{array}{c}\text { HCG dose } \\
\text { (i.u. /rat) }\end{array}$ & $\begin{array}{c}\text { No. of rats } 1 \\
\text { group }\end{array}$ & $\begin{array}{c}\% \text { rats } \\
\text { ovulating }\end{array}$ & $\begin{array}{l}\text { Mean no. of } \\
\text { ovulations } \\
\text { rat ovulating }\end{array}$ \\
\hline $\begin{array}{l}- \\
5 \cdot 0 \\
5 \cdot 0 \\
-\end{array}$ & $\begin{array}{c}- \\
\overline{10 \cdot 0} \\
10 \cdot 0\end{array}$ & $\begin{array}{r}10 \\
10 \\
8 \\
10\end{array}$ & $\begin{array}{r}0 \\
10 \\
100 \\
0\end{array}$ & $\begin{array}{c}0 \\
1 \cdot 0 \\
10 \cdot 4 \\
0\end{array}$ \\
\hline
\end{tabular}

\section{DISGUSSION}

Human chorionic gonadotrophin specifically possesses luteinizing activity (Parlow, 1961). It does not show any follicle-stimulating activity by the augmentation test of Steelman \& Pohley (1953). On the other hand, PMSG possesses predominantly FSH activity, but with a small amount of contaminant 
LH activity. Thus Catchpole (1964) was able to show in hypophysectomized females that both interstitial cells and follicles are stimulated by PMSG. The presence of contaminant LH activity has been demonstrated in the present experiments by the fact that a large dose of PMSG alone (40 i.u.) produced ovulation and luteinization in some animals treated with ovulation-inhibiting doses of ethinyl oestradiol although follicular development evidently occurred at much lower doses.

The results of the present study suggest, therefore, that megestrol acetate produces its anti-ovulatory effect purely by inhibition of $\mathbf{L H}$, thus differing from ethinyl oestradiol and testosterone propionate which exert their effects by inhibition of both LH and FsH. The results of Wolfe (1946) and Greep \& Jones (1950) suggest a similar conclusion in the case of progesterone, although Selye, Browne \& Collip (1936) and Van Rees (1959) concluded that both FSH and LH are affected by the natural hormone. Supporting evidence for the similarity in mechanism of inhibition of ovulation between megestrol acetate and progesterone is given by Kobayashi, Kobayashi, Takezawa, Oshima \& Kawamura (1962).

That ethinyl oestradiol and testosterone propionate appear to inhibit ovulation by a similar mechanism is perhaps not surprising since a survey of the literature reveals no well substantiated difference between the effects of oestrogens and androgens on the pituitary-ovarian axis of the female. Thus, although oestrogens have been reported not to produce any change in pituitary FSH levels (Paesi, de Jongh, Hoogstra \& Engbelbregt, 1955, Hoogstra \& Paesi, 1957) this does not agree with the work of Greep \& Jones (1950) who found that oestrogens gave rise to atretic follicles in the ovary suggesting decreased FSH release from the pituitary. One explanation for these contradictory results is that oestrogens may inhibit both release and synthesis of FsH, and that the resultant pituitary content is the same as in the normal animal. Testosterone propionate has also been reported to produce atrophy of follicles by Greep \& Jones (1950), although here increased FsH content of the pituitary is implicated (Greep \& Jones, 1950; Hoogstra \& Paesi, 1957).

Oestrogens and androgens are reported to decrease the LH content of the pituitary in females (Laqueur \& Fluhmann, 1942; Hellbaum \& Greep, 1946; Chowers \& McCann, 1965). Greep \& Jones (1950), however, conclude that androgens increase pituitary LH, although closer analysis of their results reveals a slight decrease in LH content of the pituitary at the higher doses of the androgen.

In the male, on the other hand, several workers agree that oestrogens have a significantly different effect from androgens: oestrogens decrease and androgens increase the FsH content of the pituitary (Paesi et al., 1955; Hoogstra \& Paesi, 1957; Van Rees, 1961). There does not seem to be any published information on comparative effects of oestrogens and androgens on levels of LH in the male.

From the results of the present experiment it is suggested that testosterone propionate exerts an effect on the gonad-pituitary axis in the female different from that in the male rat. The effect in the former is identical with that produced by oestrogen administration so that, although there are three structural gonadal hormones, they may be characterized in the female into the two functional 
groups possessing oestrogenic and progestagenic activities. A possible explanation of this phenomenon could be that androgens are converted to oestrogens in the ovary, suggested by results obtained by Bresloff, Oakey \& Stitch (1966).

\section{REFERENCES}

Bennett, J. P., Vallance, D. K. \& Vickery, B. H. (1967) A method for the direct observation of ovulation inhibition in the mature rat. F. Reprod. Fert. 13, 567.

Bresloff, P., OAKEy, R. E. \& STIrch, S. R. (1966) Biosynthesis in vitro of oestrogen by rat ovaries from tritiated dehydroepiandrosterone and testosterone. 7. Endocr. 35, xvii.

GAtchPole, H. R. (1964) Gonadotrophins: their chemical and biological properties and secretory control, p. 40. Ed. H. H. Gole. W. H. Freeman, San Francisco and London.

Chowers, I. \& MCCANN, S. M. (1965) Content of luteinising hormone-releasing factor and luteinising hormone during the estrous cycle and after changes in gonadal steroid titers. Endocrinology, 76, 700.

Greep, R. O. \& Jones, C. I. (1950) Steroid control of pituitary function. Recent Prog. Horm. Res. 5, 197.

Hellbaum, A. A. \& Greep, R. O. (1946) Action of oestrogens on release of hypophyseal luteinising hormone. Proc. Soc. exp. Biol. Med., 63, 53.

Hoogstra, M. J. \& Paesi, F. J. A. (1957) The FSH content of the hypophysis of the rat as influenced by androgen. Acta endocr., Copenh. 24, 353.

Kobayashi, T., Kobayashi, T., Takezawa, S., Oshima, K. \& Kawamura, H. (1962) Electrophysiological studies on the feedback mechanism of progesterone. Endocr. jap. 9, 302.

LaQueur, G. L. \& Fluhmann, C. F. (1942) Action of testosterone on female rat hypophysis. Endocrinology, 31,300 .

Makepeace, A. W., Weinstein, G. L. \& Friedman, M. H. (1937) The effect of progestins and progesterone on ovulation in the rabbit. Am. F. Physiol. 119, 512.

Paesi, F. J. A., De Jongh, S. E., Hoogstra, M. J. \& Engelbregt, A. (1955) Follicle-stimulating hormone content of hypophysis of rat as influenced by gonadectomy and oestrogen treatment. Acta endocr., Copenh. 19, 49.

Parlow, A. F. (1961) A rapid bioassay for LH and factors stimulating LH secretion. Fedn Proc. Fedn Am. Socs exp. Biol. 17, 402.

Selye, H., Browne, J. S. L. \& Collip, J. B. (1936) Effects of large doses of progesterone in the female rat. Proc. Soc. exp. Biol. Med. 34, 472.

Steelman, S. L. \& Pohley, F. M. (1953) Assay of the follicle-stimulating hormone based on the augmentation with human chorionic gonadotrophin. Endocrinology, 53, 604.

VAN REEs, G. P. (1959) The effect of progesterone on the ICSH and FSH content of anterior pituitary and blood serum. Acta physiol. pharmac. néerl. 8, 195.

VAN REES, G. P. (1961) Influence of steroid sex hormones on the FSH release by rat hypophyses in vitro. Acta endocr., Copenh. 36, 485.

Wolfe, M. J. (1946) Effects of progesterone on the cells of the anterior hypophysis of the rat. Am. $\mathcal{J}$. Anat. 79, 199. 